\title{
PROFILE SMK MULTIMEDIA MANDIRI MELALUI WEBSITE SEBAGAI PENUNJANG MEDIA INFORMASI
}

\section{PROFILE OF MULTIMEDIA MANDIRI VOCATIONAL HIGH SCHOOL AS A MEDIA INFORMATION SUPPORT}

\author{
Dewi Immaniar Desrianti ${ }^{1}$ \\ Achmad Rizal Kurniawan ${ }^{2}$ \\ Program Studi Teknik Informatika, STMIK Raharja \\ Email: dewi.immaniar@ raharja.info ${ }^{1)}$, rizal.kurniawan@ raharja.info ${ }^{2)}$
}

\begin{abstract}
ABSTRAK
Selaras dengan semakin canggihnya media informasi pada saat ini, penggunaan website sebagai sarana media penunjang informasi sudah umum digunakan. Website merupakan halaman digital yang berisi suatu data-data atau suatu informasi yang sudah dipublikasikan secara umum oleh individu, kelompok, maupun sebuah organisasi tertentu. Dibandingkan dengan media informasi yang sebelumnya seperti koran, poster, spanduk, majalah, dan televisi, website sekarang ini lebih dikenal di masyarakat. Namun SMK Multimedia Mandiri belum mempunyai website sebagai media informasi, sehingga sosialisasi dan penyampaian informasi yang diterima di masyarakat luas terasa kurang tersampaikan. Maka dari itu dengan adanya penelitian ini dibuatlah website yang bertujuan sebagai media informasi sekolah, memperkenalkan SMK Multimedia Mandiri ke masyarakat luas, menyampaikan informasi seputar lingkungan sekolah, serta memberikan kemudahan bagi calon siswa siswi yang akan mendaftar. Pada penelitian kali ini digunakan metode observasi, wawancara/interview, studi pustaka, studi literatur, identifikasi analisa kebutuhan, dan juga perancangan media. Website yang akan dibuat menggunakan bahasa HTML, MySQL, Javascript, PHP, dan CSS sebagai bahasa pemrograman, dan menggunakan software Dreamweaver dalam perancangannya. Dengan dibuatnya penelitian ini diharapkan dapat menghasilkan website yang berguna sebagai media komunikasi, media sosialisasi, media informasi, dan juga sebagai media promosi.
\end{abstract}

Kata kunci: Website, Profil, Sekolah, Internet.

\begin{abstract}
Aligned with the increasingly sophisticated information media at this time, the use of the website as a supporting media information is commonly used. Website is a digital page that contains a data or an information that has been published in general by an individuals, groups, or a particular organization. Compared to the previous media information such as newspapers, posters, banners, magazines, and television, website is now better known in the community. However Multimedia Mandiri Vocational Highschool is still didn't have a website in their school, so the socialization and the information delivery that received in the wider community was less than conveyed. Therefore this research is to make a website that aims as a school promotion media, introducing Multimedia Mandiri Vocational Highschool to the public via internet and website, give more information about the school environment, and provide convenience for prospective students who will regist. The website will be created using HTML, MYSQL, Javascript, PHP and CSS as the programming languages, and using Dreamweaver software in its design. The method that we used in this research are observation method, interview method, literature study, and also the identification of needs requirement from website that we want to make. This research is expected to make a useful website as a media of communication, socialization media, information media, and also as a campaign media.
\end{abstract}

Keywords: Website, Profile, School, Internet. 


\section{PENDAHULUAN}

Internet di era digital pada saat ini telah menjadi ruang publik. Internet merupakan sebuah singkatan dari Interconnecting Network. Sudah banyak masyarakat yang mengakses, menggunakan, dan memanfaatkan internet untuk mencari suatu informasi, meski pada era globalisasi saat ini pelayanan informasi sangat cepat, namun sangat sulit untuk mendapatkan informasi yang akurat, tepat, dan terpercaya. Oleh karena itu jenis data dan informasi yang memadai sangat dibutuhkan bagi semua orang. Bila diperhatikan dari perkembangan media sarana informasi yang ada, perkembangan pada sarana informasi komputer lah yang jauh lebih cepat, salah satu dari sarana tersebut adalah media internet dan website. Internet adalah sekumpulan jaringan komputer yang saling terhubung secara fisik dan memiliki kemampuan untuk membaca dan menguraikan protokol komunikasi tertentu yang disebut Internet Protocol (IP) dan Transmission Control Protocol (TCP). Protokol adalah spesifikasi sederhana mengenai bagaimana komputer saling bertukar informasi [1]. Teknologi internet sangat cepat diterima di semua kalangan masyarakat, dan dapat dimanfaatkan untuk berbagai keperluan oleh siapapun, dimanapun, dan kapanpun. Sangat banyak teknologi di dalam internet yang dapat digunakan dan dimanfaatkan, salah satunya adalah tersedianya berbagai informasi yang dikemas dalam banyak bentuk, misalnya dalam bentuk teks, gambar, suara, maupun video. Dengan fasilitas tersebut website dapat menjadi sangat dikenal oleh masyarakat luas dan berkembangnya website sendiri sangatlah pesat. Website adalah fasilitas internet yang menghubungkan dokumen dalam lingkup lokal maupun jarak jauh. Dokumen pada website disebut dengan web page dan link dalam website memungkinkan pengguna bisa berpindah dari satu page ke page lain (hyper text), baik diantara page yang disimpan dalam server yang sama maupun server di seluruh dunia [2]. Website mempunyai banyak macam, mulai dari website yang sederhana hingga website yang dinamis. Proses pembuatan website pun beragam, ada yang mudah juga ada yang sulit tergantung dengan kebutuhannya. Website biasanya mempunyai fungsi yang bermacam-macam. Di dalam dunia pendidikan, website berfungsi untuk memberikan informasi-informasi mengenai sekolah kepada siswa-siswinya maupun ke masyarakat luas. Menurut buku Analisis dan Desain Sistem Informasi yang ditulis oleh Jogianto, Informasi adalah suatu data yang sudah diproses dalam bentuk yang lebih baik, mempunyai nilai guna atau bermanfaat untuk orang yang mendapatkannya. Hasil proses data tersebut memberikan gambaran mengenai suatu kejadian (event) yang nyata (fact) yang bisa digunakan untuk membuat maupun mengambil keputusan [3].

Sekolah Menengah Kejuruan (SMK) merupakan jenjang yang lebih tinggi dari Sekolah Menengah Pertama (SMP) selain Sekolah Menengah Atas (SMA) yang lebih mengutamakan ke keterampilan para peserta didiknya. SMK Multimedia Mandiri merupakan sekolah menengah kejuruan yang membuka jurusan Teknik Komputer Jaringan (TKJ) yang terletak di Jl. Raya Kedoya No. 2, RT005/004, Kedoya Sel., Kb. Jeruk, Daerah Khusus Ibukota Jakarta, dimana dengan adanya jurusan tersebut diharapkan dapat menjadi sarana pencetak tenaga terampil, kreatif, dan inovatif dalam dunia jaringan komputer. Diharapkan pula untuk dapat menampung para siswa/i yang mempunyai potensi keingintahuan yang tinggi dalam program teknik komputer jaringan.

Di zaman yang serba digital ini masyarakat sudah banyak memanfaatkan internet untuk mencari suatu informasi, salah satu informasi yang sering kali dicari oleh masyarakat yaitu website mengenai sebuah sekolah. Dengan adanya internet maka sekolah-sekolah yang ada saat ini dimudahkan untuk menyampaikan suatu informasi serta tidak perlu mengeluarkan biaya lebih untuk mempromosikan sekolahnya menggunakan spanduk dan lain sebagainya. Banyak sekolah yang sudah memanfaatkan internet dengan cara membuat website sekolah sebagai sarana promosi dan informasi untuk memudahkan masyarakat mengetahui profil sekolahnya, sehingga masyarakat tidak perlu repot-repot datang ke sekolah. Karena SMK Multimedia Mandiri belum mempunyai sebuah website, maka dibuatlah website sekolah yang bertujuan sebagai media promosi, memperkenalkan SMK Multimedia Mandiri, dan memberikan informasi seputar lingkungan sekolah juga memberi kemudahan bagi calon siswa/i yang akan 
mendaftar. Menurut penelitian yang dilakukan oleh Suyatno dan Tri Irianto Tj dalam jurnal Pembuatan Website Profil Sekolah Dasar Negeri 03 Karangsari Jatiyoso, sekolah yang belum mempunyai website berdampak negatif pada masyarakat yang sulit mencari informasi mengenai profil sekolah [4].

Dalam pembuatan website ini menggunakan bahasa pemrograman HTML, MySQL, Javascript, dan CSS, dan juga menggunakan software Dreamweaver dalam perancangannya. HTML digunakan untuk membuat sebuah website, website yang dibuat menggunakan HTML ini dapat dilihat secara publik dengan koneksi internet menggunakan sebuah browser. HTML merupakan sebuah bahasa berformat teks untuk suatu dokumen yang ada di jaringan komputer world wide web [5]. Definisi HTML yaitu suatu format yang digunakan untuk membuat dokumen atau suatu aplikasi yang ada di halaman web [6]. HTML adalah bahasa yang digunakan untuk membuat suatu web, umumnya memakai format .htm, .html atau .shtml [7]. Selain untuk membuat halaman web, HTML juga memiliki fungsi sebagai dasar dari sebuah website, untuk menambahkan suatu objek seperti gambar, audio, video, dll, dan juga berfungsi untuk membuat formulir online.

CSS (Cascading Style Sheet) merupakan style yang berguna untuk memperlihatkan elemen sebuah HTML yang dapat mengatur tampilan sebuah web juga memisahkan antar tampilan dan isi sebuah halaman web. Menggunakan CSS dapat mempercantik halaman sebuah web sehingga terlihat lebih menarik. Untuk mempermudah pembuatan website saat ini sudah tersedia software untuk membuat website yaitu Adobe Dreamweaver. Dreamweaver merupakan sebuah software yang dibuat oleh Adobe System yang berguna untuk membuat atau mengubah halaman web. Aplikasi ini memberikan kemudahan untuk penggunanya karena sudah banyak fitur pendukung dalam teknologi saat ini.

Selain kemudahan yang diberikan untuk penggunanya karena banyak fitur pendukung, salah satu fitur yang banyak menarik pengguna Dreamweaver yaitu What You See Is What You Get (WYSIWYG), atau bila dalam aplikasi Dreamweaver sering kita kenal dengan Design View. Maksud dari fitur tersebut adalah tampilan hasil akhir web yang telah dibuat bisa diketahui seiring dengan berjalannya proses perancangaan dan desain web.

Oleh karena itu, pemilihan Dreamweaver sebagai software yang digunakan dalam pembuatan website Sekolah Menengah Kejuruan (SMK) Multimedia Mandiri dinilai baik, karena dapat menciptakan website sekolah yang dinamis, dengan tampilan interaktif, dan diharapkan dapat menjadi penunjang media informasi bagi sekolah, selain itu dapat mempermudah siswa/i maupun calon siswa/i yang ingin mencari informasi mengenai sekolah namun dengan akses yang mudah dan praktis.

\section{METODE PENELITIAN}

Serangkaian pelaksanaan penelitiaan yang dilakukan adalah analisa masalah, pengumpulan data, analisa sistem, dan implementasi. Gambar di bawah ini merupakan bagan dari metode penelitian yang dilakukan. 


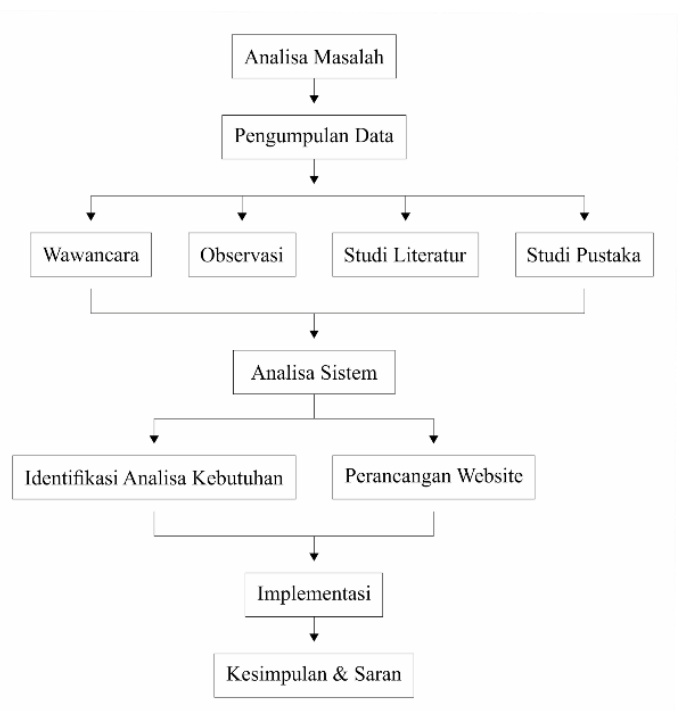

Gambar 1. Bagan Metode Penelitian

Pada Gambar 1, tahap pertama dari metode penelitian yaitu analisa masalah, setelah menemukan dan menganalisa masalah, pada tahap berikutnya dilakukanlah pengumpulan datadata yang diperlukan dalam kegiatan penelitian, metode pengumpulan data tersebut antara lain adalah observasi, wawancara, studi literatur, dan studi pustaka. Setelah metode pengumpulan data dilakukan, tahapan selanjutnya yaitu analisa sistem, saat memasuki tahap analisa sistem dilakukan identifikasi analisa kebutuhan dan perancangan website, setelah itu dilakukanlah tahap implementasi.

Metode analisa permasalahan yang digunakan yaitu dengan observasi dan interview. Rumusan permasalahan telah didapatkan dari hasil interview yang dilakukan pada hari Kamis 25 Januari 2018 bertempat di Sekolah Menengah Kejuruan (SMK) Multimedia Mandiri dengan Bapak Slamet R selaku kepala sekolah dari Sekolah Menengah Kejuruan (SMK) Multimedia Mandiri, berdasarkan interview yang telah dilakukan telah dirumuskan beberapa masalah yaitu: Belum adanya website Sekolah Menengah Kejuruan (SMK) Multimedia Mandiri, Promosi Sekolah Menengah Kejuruan (SMK) Multimedia Mandiri masih menggunakan media cetak, siswa/i yang telah terdaftar ataupun calon siswa/i yang ingin mendaftar harus datang ke sekolah untuk mencari setiap informasi terbaru tentang sekolah. Dari tiga rumusan masalah tersebut maka solusi yang ingin dibuat untuk memecahkan rumusan masalah yang telah diperoleh yaitu dengan membuat website sekolah, yang di dalam website sekolah nantinya akan terdapat banyak informasi dan data mengenai Sekolah Menengah Kejuruan (SMK) Multimedia Mandiri, sehingga informasi yang ada pada sekolah dapat tersampaikan dengan lebih baik.

Metode pengumpulan data untuk mendapatkan data-data yang diperlukan yaitu dengan cara metode wawancara \& interview, data dan informasi yang diperoleh dari metode wawancara \& interview dilakukan melalui tanya jawab langsung dengan stakeholder Bapak Slamet $\mathrm{R}$ selaku kepala sekolah Sekolah Menengah Kejuruan (SMK) Multimedia Mandiri. Selanjutnya melakukan Observasi dengan mendatangi langsung tempat penelitian di Sekolah Menengah Kejuruan (SMK) Multimedia Mandiri, data, dan hal-hal yang diperlukan dalam perancangan dan penyusunan website yang akan dibuat telah didapatkan dari metode observasi tersebut. Tahap berikutnya ialah melakukan studi literatur dengan mencari data-data yang diperlukan sebagai materi acuan dan referensi, data tersebut diperoleh dari jurnal-jurnal yang telah terbit sebelumnya dan yang telah dicantumkan ke dalam literature review. Selain literature review, pengumpulan data juga dilakukan dengan cara studi pustaka, data yang diperoleh melalui studi pustaka yaitu merupakan materi-materi yang digunakan sebagai bahan referensi, dan acuan dari berbagai sumber. 
Setelah metode pengumpulan data telah selesai dilakukan, selanjutnya yang akan dilakukan adalah tahap metode analisa sistem, terdapat dua hal yang ada di dalam proses analisa sistem, yaitu identifikasi analisa kebutuhan dan perancangan website. Dalam identifikasi analisa kebutuhan, dilakukan wawancara, dan interview dengan stakeholder dalam menentukan kebutuhan dan keinginan stakeholder pada website yang akan dibuat, stakeholder juga memberikan system requirements dari website Sekolah Menengah Kejuruan (SMK) Multimedia Mandiri. Tahapan berikutnya setelah analisa sistem, terdapat proses perancangan website yang dilakukan setelah mengetahui apa yang dibutuhkan dan diinginkan dari pihak stakeholder. Website dirancang menggunakan software Dreamweaver, bahasa pemrograman yang digunakan dalam pembuatan website adalah HTML, MySQL, Javascript, PHP dan CSS dengan mengacu pada system requirements yang telah diberikan dan disepakati bersama dengan stakeholder.

Metode implementasi merupakan metode penelitian terakhir yang dilakukan, dalam tahap implementasi dilakukan penerapan dari website yang telah dibuat ke Sekolah Menengah Kejuruan (SMK) Multimedia Mandiri, di dalam tahap implementasi pula nantinya terdapat kritik dan saran yang akan digunakan untuk maintenance kembali website yang telah dibuat.

\section{HASIL DAN PEMBAHASAN}

Setelah melakukan beberapa metode penelitian dan mengumpulkan data serta informasi yang dibutuhkan, dilakukanlah proses perancangan website SMK Multimedia Mandiri, proses perancangan website meliputi pembuatan diagram use case dan sequence dari website yang akan dibuat. Berikut adalah penjelasan dari masing-masing diagram yang telah dirancang.

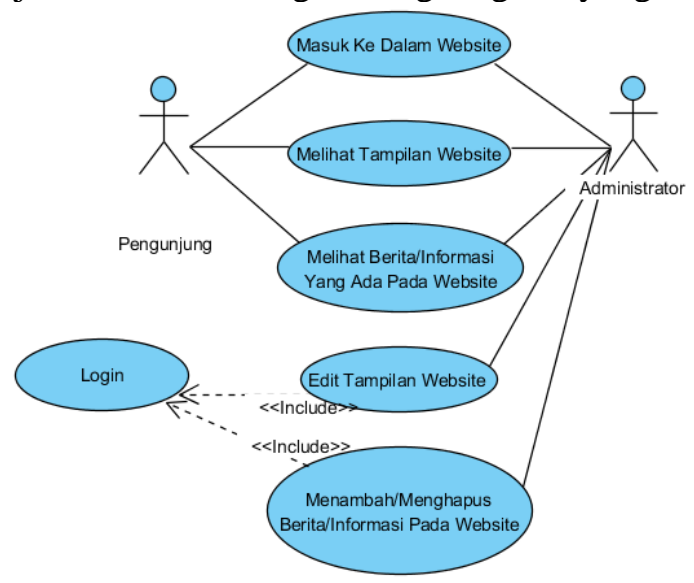

Gambar 2. Use Case Diagram Website

Terdapat dua actor pada gambar diagram use case di atas, yaitu pengunjung dan administrator dimana actor pengunjung adalah para siswa/i, staff sekolah, guru, dan siapapun yang mengakses website sekolah, sedangkan administrator merupakan seorang yang menjadi pengurus website. Pengunjung hanya dapat masuk ke dalam website, melihat tampilan website, dan melihat berita atau informasi yang terdapat pada website, karena pengunjung tidak mempunyai hak akses yang sama dan setingkat dengan administrator. Menu-menu yang dapat diakses oleh pengunjung akan dijelaskan pada pembahasan selanjutnya. Actor yang kedua yaitu administrator, hak akses yang dimiliki oleh administrator lebih tinggi daripada pengunjung, administrator dapat melakukan apa yang pengunjung lakukan (masuk ke dalam website, melihat tampilan website, dan melihat berita atau informasi yang terdapat pada website) namun ada hal yang pengunjung tidak bisa lakukan, dan hanya administrator yang dapat melakukannya yaitu, melakukan edit pada tampilan website dan menambah atau menghapus berita serta informasi yang terdapat pada website, untuk dapat melakukan itu semua administrator harus terlebih dahulu login ke dalam website dengan username dan password yang telah dimiliki untuk mendapatkan hak akses sebagai administrator. Selanjutnya akan dilakukan pembahasan mengenai sequence diagram. 


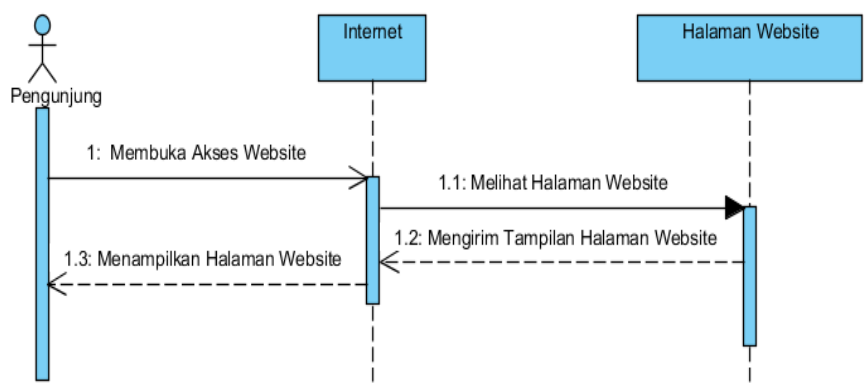

Gambar 3. Sequence Diagram (User)

Actor yang terdapat pada sequence diagram yang pertama yaitu pengunjung atau user, hal yang pertama harus dilakukan pengunjung untuk menuju website sekolah yaitu dengan membuka akses website melalui internet, dengan cara memasukkan alamat dari website yang telah dibuat, dan ditentukan alamatnya melalui browser. Setelah itu internet akan memberi koneksi untuk melihat halaman website sekolah dari alamat yang telah dimasukkan sebelumnya, interaksi yang terjadi antara internet dengan halaman website yaitu, internet mengunggah alamat website yang telah dimasukkan oleh pengunjung, setelah itu halaman website akan terkirim kepada pengunjung dengan cara pengunduhan informasi yang dilakukan oleh internet. Berikutnya akan dilakukan pembahasan mengenai sequence diagram dari administrator.

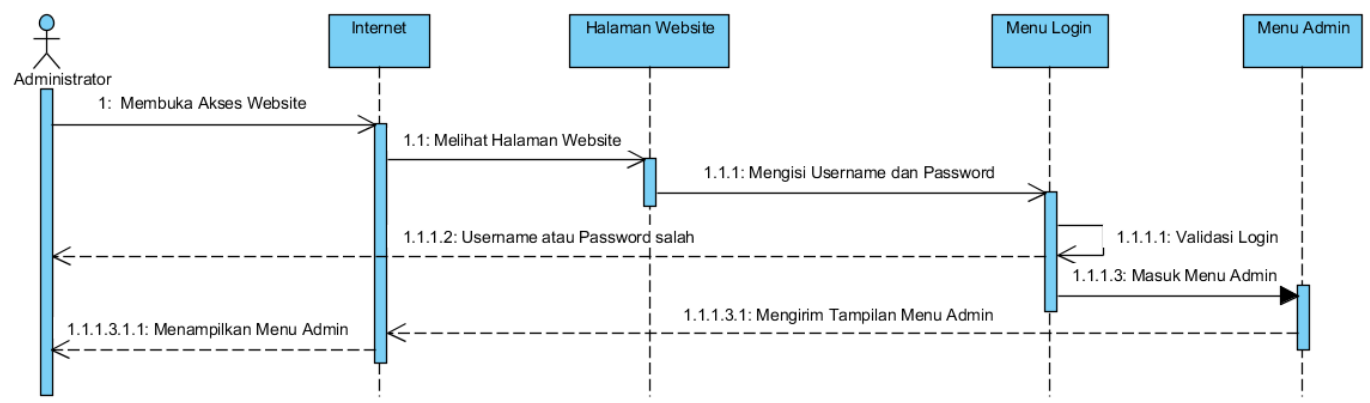

Gambar 4. Sequence Diagram (Administrator)

Gambar di atas merupakan sequence diagram dengan actor sebagai administrator yang mempunyai hak akses untuk melakukan maintenance pada website. Hal yang harus dilakukan pertama kali oleh administrator untuk melakukan maintenance pada website yaitu sama dengan pengunjung pada awalnya, yaitu membuka akses website melalui internet dengan cara mengakses alamat website yang telah diketikkan dan dimasukkan ke dalam browser. Yang berbeda dari sequence diagram administrator dengan sequence diagram user atau pengunjung ialah, terdapat menu login yang diakses oleh administrator, setelah masuk pada halaman menu login, administrator memasukkan username dan password yang nantinya akan dilakukan validasi login pada menu tersebut. Apabila username dan password yang dimasukkan oleh administrator salah, maka akan ditampilkan pemberitahuan bahwa "Username atau Password salah" sedangkan jika benar administrator akan masuk ke dalam menu admin dan dapat melakukan maintenance pada website. Maintenance yang dilakukan pada website dapat berupa penambahan berita atau informasi terbaru mengenai sekolah, ataupun memperbaharui layout dan tampilan dari website itu sendiri.

Gambar di bawah ini adalah tampilan awal website sekolah yang telah dibuat dari hasil perancangan melalui diagram use case dan diagram sequence yang telah ditampilkan dan dijelaskan sebelumnya, tampilan awal website sekolah ini berisi menu-menu yang dapat diakses oleh user level pengunjung. 


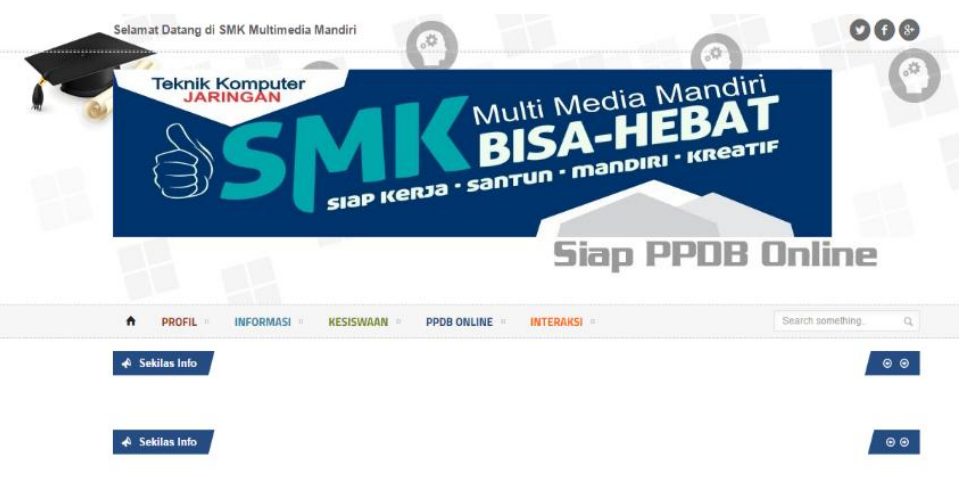

Gambar 5. Halaman Utama Website

Gambar 5 merupakan tampilan utama dari halaman website SMK Multimedia Mandiri yang telah dirancang, pada halaman utama website terdapat beberapa menu yaitu Profil, Informasi, Kesiswaan, PPDB Online, dan Interaksi. Berikut ini gambar dan pembahasan pada masing-masing menu yang terdapat pada website SMK Multimedia Mandiri.

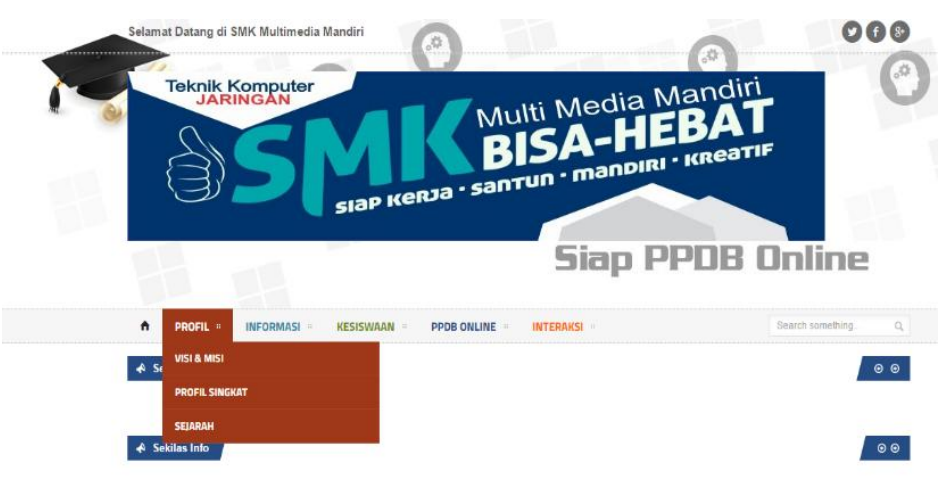

Gambar 6. Sub Menu Profil

Pada menu utama apabila cursor mouse diarahkan ke pada masing-masing menu, maka akan muncul sub menu dari masing-masing menu utama. Pada menu Profil terdapat sub menu Visi \& Misi, Profil Singkat, dan Sejarah. Sub menu Visi \& Misi berisi visi dan juga misi dari didirikannya SMK Multimedia Mandiri, sub menu Profil Singkat merupakan pengenalan singkat pada sekolah, dan pada sub menu Sejarah terdapat sejarah dari SMK Multimedia Mandiri.

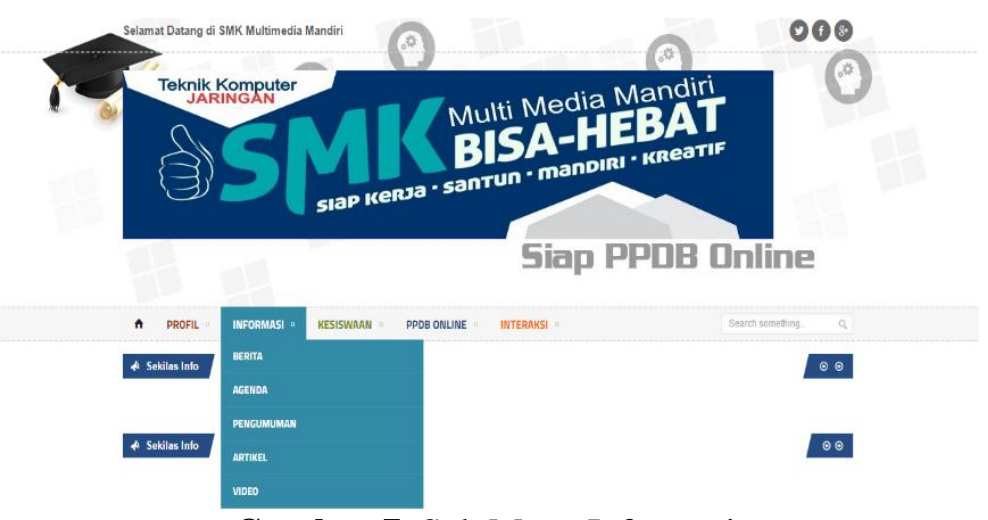

Gambar 7. Sub Menu Informasi

Menu informasi berisi sub-sub menu yang berkaitan dengan suatu informasi-informasi yang dibutuhkan oleh siswa/i. Apabila siswa/i sedang mencari informasi mengenai apa yang 
sedang terjadi di sekitar sekolah maka dapat ditemukan dari sub menu Berita dan memilih sub menu Agenda untuk mencari informasi tentang agenda kegiatan belajar mengajar di sekolah. Sub menu Pengumuman akan memberi informasi kepada siswa/i tentang pengumuman terbaru yang mungkin dilewatkan oleh siswa/i tersebut, sedangkan sub menu Artikel dan Video berisi tentang kumpulan bacaan \& video untuk memperluas pengetahuan para siswa/i.

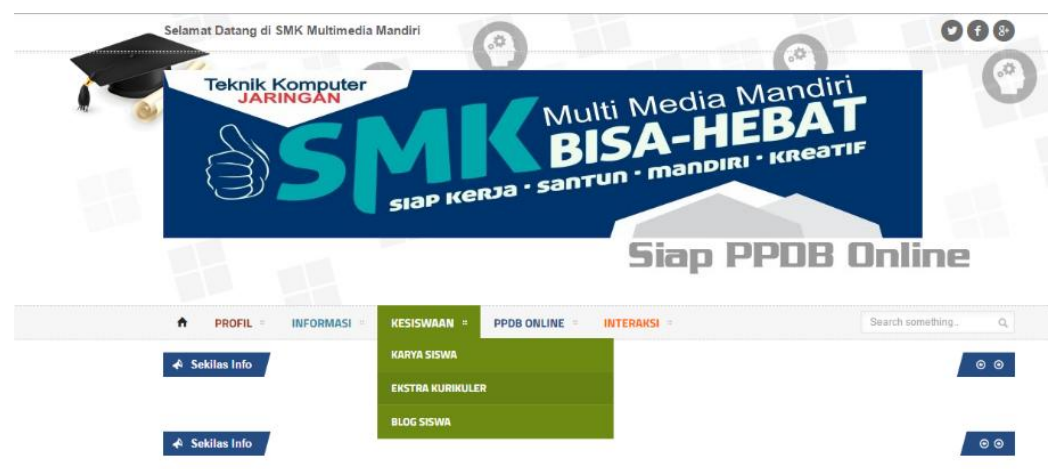

Gambar 8. Sub Menu Kesiswaan

Menu selanjutnya yaitu menu Kesiswaan, di dalam menu Kesiswaan terdapat tiga sub menu yaitu menu Karya Siswa, Ekstra Kurikuler, dan Blog Siswa. Di dalam sub menu Karya Siswa akan ditampilkan karya-karya siswa yang telah dibuat dalam bentuk seperti gambar, video, ataupun artikel, sedangkan pada sub menu Ekstra Kurikuler akan terdapat pengenalan singkat mengenai berbagai macam jenis ekstra kurikuler yang terdapat pada SMK Multimedia Mandiri. Sub menu terakhir yang terdapat dalam menu Kesiswaan yaitu Blog Siswa, isi dari sub menu Blog Siswa merupakan kumpulan list dari alamat blog yang dimiliki oleh siswa/i di SMK Multimedia Mandiri.

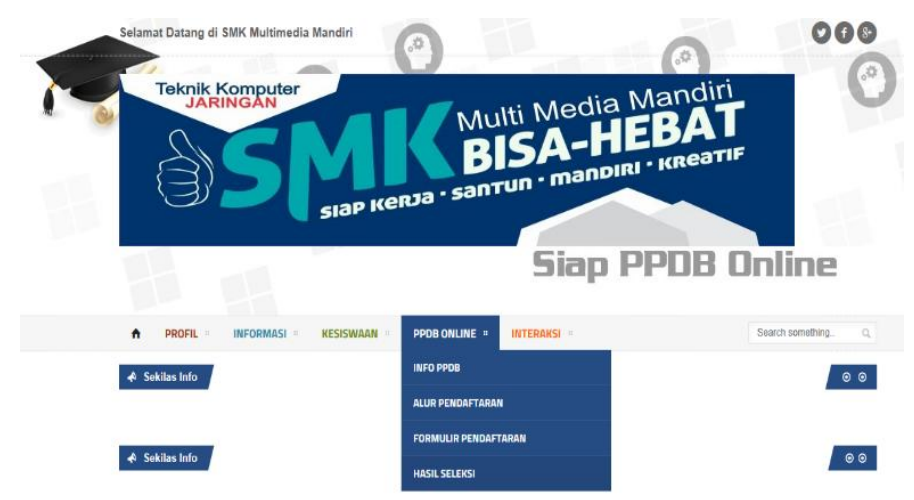

Gambar 9. Sub Menu PPDB

Dalam menu PPDB Online terdapat sub menu Info PPDB, Alur Pendaftaran, Formulir Pendaftaran, dan Hasil Seleksi. Menu PPDB Online sebenarnya dikhususkan bagi calon siswa/i yang telah lulus SMP, dan ingin mendaftar pada SMK Multimedia Mandiri secara online. Sub menu Info PPDB berisi tentang segala informasi yang calon siswa/i butuhkan mengenai pendaftaran online pada SMK Multimedia Mandiri, selanjutnya pada sub menu Alur Pendaftaran akan dijelaskan bagaimana tata cara, dan tahapan dalam melakukan pendaftaran online, meliputi pencetakan atau download formulir pendaftaran online yang terdapat pada sub menu formulir pendaftaran, sub menu terakhir pada menu PPDB adalah sub menu Hasil Seleksi, di dalam sub menu hasil seleksi akan muncul daftar nama-nama calon siswa/i yang berhasil lulus dari hasil test yang diberikan SMK Multimedia Mandiri. 


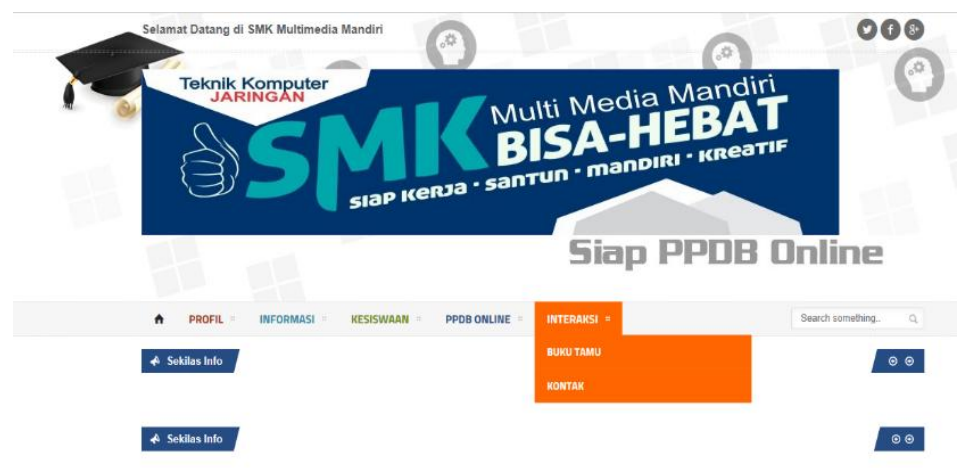

Gambar 10. Sub Menu Interaksi

Menu terakhir yang ada pada website adalah menu Interaksi, di dalam menu Interaksi terdapat sub menu Buku Tamu dan Kontak. Sub menu Buku Tamu akan memberikan pengunjung website wadah untuk berinteraksi dengan pengolah website dan memberi masukan mengenai website yang telah dibuat, sedangkan sub menu Kontak berisi kontak SMK Multimedia Mandiri seperti nomor telepon sekolah yang bisa dihubungi dan kontak lainnya.

Setelah dilakukan pembahasan mengenai menu-menu yang ada pada tampilan halaman utama website, selanjutnya akan dilakukan penjelasan mengenai form login dan menu administrator. Untuk masuk dan mengakses menu administrator terlebih dahulu harus memasukkan username dan password ke dalam form login, gambar di bawah ini merupakan gambar dari form login, tempat dimana administrator memasukkan username dan password untuk masuk ke dalam tampilan atau halaman menu admin.

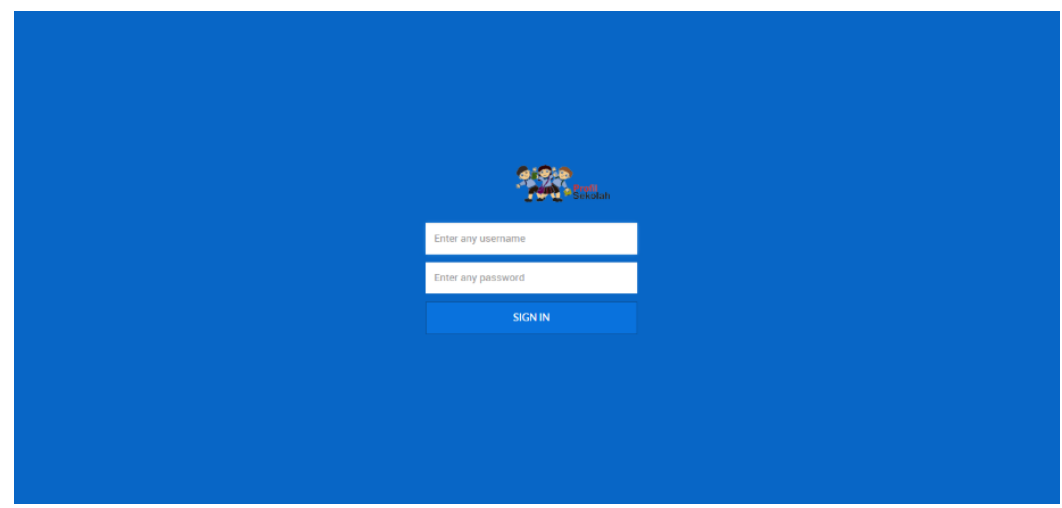

Gambar 11. Form Login

Tampilan form login pada gambar di atas terdapat dua textbox dan satu command button dimana textbox pertama berisi "Enter any username" yang berarti pengguna harus memasukkan nama atau username yang telah terdaftar untuk masuk ke dalam menu halaman selanjutnya, yaitu menu administrator. Sedangkan pada textbox kedua terdapat tulisan "Enter any password" dimana pengguna harus memasukkan password dari username yang telah dimasukkan sebelumnya. Berikut adalah gambar yang akan tampil apabila pengguna berhasil memasukkan username dan password dengan benar. 


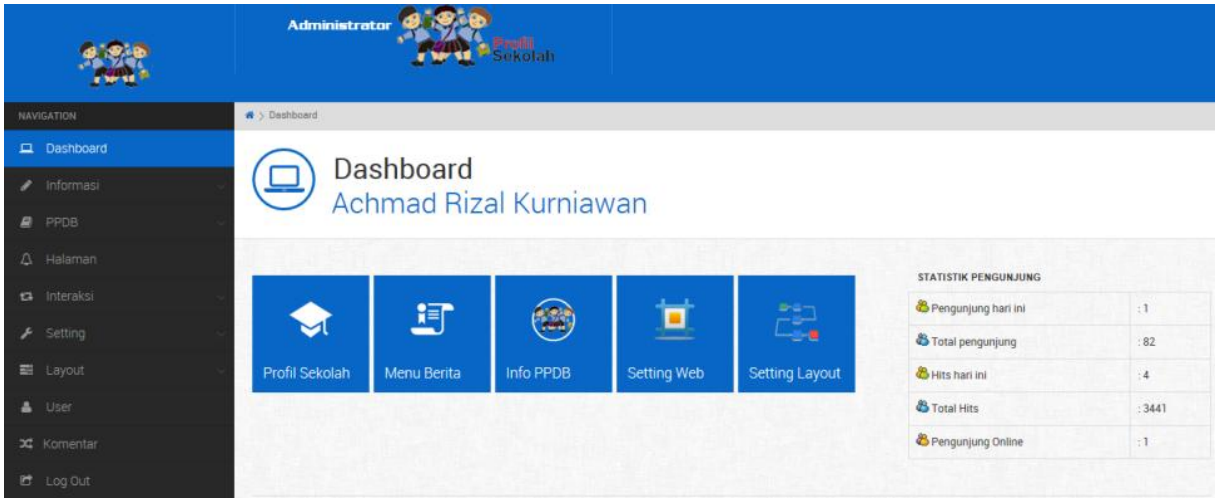

Gambar 12. Menu Administrator

Gambar 12 merupakan tampilan pada halaman menu administrator yang muncul setelah pengguna sebelumnya berhasil memasukkan username dan password dengan benar. Pada gambar di atas terdapat menu-menu yang hanya bisa diakses dan dibuka oleh seorang administrator yaitu menu-menu yang berada pada bar sebelah kiri seperti Dashboard, Informasi, PPDB, Halaman, Interaksi, Setting, Layout, User, Komentar, dan Logout. Menumenu tersebut dapat diakses oleh administrator apabila seorang administrator ingin menambahkan konten atau informasi yang terdapat di dalam website atau bahkan mengubah tampilan layout dari halaman website sekolah.

\section{KESIMPULAN}

Dengan diadakannya penelitian ini dan dilakukan implementasi terhadap website yang telah dibuat maka SMK Multimedia Mandiri telah mempunyai website sekolah, sehingga informasi yang tersampaikan ke lingkungan sekolah maupun masyarakat luas sudah lebih efisien dan mencakup area yang lebih luas, selain itu website sekolah ini juga memudahkan masyarakat untuk mengetahui informasi seputar sekolah SMK Multimedia Mandiri tanpa harus jauh-jauh datang langsung ke sekolah karena website dapat diakses kapanpun, dimanapun, dan oleh siapapun selama perangkat yang digunakan tersambung dengan koneksi internet. Dengan adanya website sekolah pada SMK Multimedia Mandiri ini juga telah membuktikan bahwa SMK Multimedia Mandiri telah menjadi sekolah yang mengikuti perkembangan teknologi dan memanfaatkan koneksi internet dengan baik. Website yang telah dirancang juga telah memudahkan siswa/i SMK Multimedia Mandiri dalam kemudahan mencari informasi, berita terbaru, dan pengumuman yang ada pada sekolah.

\section{SARAN}

Diharapkan website sekolah SMK Multimedia Mandiri ini dapat dikelola, diperbarui, dan dimaintenance secara berkala sehingga penyampaian informasi yang ada dapat lebih tepat dan akurat, selain itu juga diharapkan melakukan penambahkan konten-konten pada website sehingga tampilan website sekolah lebih menarik, memperbaiki bug yang masih terdapat pada website, dan penambahan informasi-informasi di dalam website yang terus dibutuhkan oleh para siswa/i, guru dan staff sekolah, juga masyarakat di luar lingkungan sekolah. Semoga kedepannya website sekolah ini dapat terus berkembang dan tetap mengikuti perkembangan terhadap hal yang sedang terjadi pada lingkungan sekolah maupun di luar lingkungan sekolah, serta diharapkan juga website sekolah ini menjadi website yang dapat mencakup kegiatan belajar mengajar secara online. 


\section{DAFTAR PUSTAKA}

[1] Allan, 2005, Pengertian Internet Dan Asal Usul Dari Kata Internet, Penerbit Indah, Surabaya

[2] Hakim, Lukmanul dan Uus Musalini, 2004, Cara Cerdas Menguasai Layout, Desain dan Aplikasi Web, PT. Elex Media Komputindo, Jakarta

[3] Jogianto, HM, 2005, Analisi dan Desain Sistem Informasi, Penerbit Andi, Yogyakarta

[4] Suyatno, Tri Iriyanto Tj, 2013, Pembuatan Website Profile Sekolah Dasar Negeri 03 Karangsari Jatiyoso, Vol. 2 No. 1

[5] Bunafit, Nugroho, 2006, Membuat Aplikasi Sistem Pakar dengan PHP dan My SQL dengan Editor Dreamweaver, Ardana Media, Yogyakarta

[6] Arief M Rudianto, 2011, Pemrograman Web Dinamis menggunakan PHP dan My SQL, CV Andi Offset, Yogyakarta

[7] Suyanto, Asep Herman, 2007, Web Design Theory and Pratices, Andi, Yogyakarta 